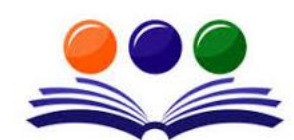

GRAND ACADEMIC PORTAL RESEARCH JOURNALS

\section{GAP INTERDISCIPLINARITIES \\ A Global Journal of Interdisciplinary Studies \\ ( ISSN - 2581-5628) \\ Impact Factor: SJIF - 5.047, IIFS - 4.875}

\title{
REGIONAL RURAL BANK'S FOUR AND A HALF DECADE JOURNEY
}

\author{
Dr. Ashok D. Revankar \\ Principal, Smt. Indira Gandhi First Grade College For Women \\ Sagara, Karnataka, India. \\ ashokrevankar@rediffmail.com
}

\begin{abstract}
Regional Rural Banks have been conceived mainly for meeting the requirements of ruralites and to uplift them by providing necessary timely financial assistance. The regional Rural banks appeared in the Indian banking map with a number of objectives. In spite of their success and failure, these banks definitely tried to reach the rural mass. These banks which emerged as new species in the arena of Indian banking system have done a good work and have to travel a long way by facing many challenges. In the process of rural development certainly Regional Rural Banks are playing crucial role. Their existence is necessary, and they have to come out with strong, viable institutions in the days to come.
\end{abstract}

Keywords: RRBS, NPA, C.D. Ratio

\section{PRELUDE}

Regional Rural Banks popularly known as Gramin Banks in the Indian banking sector are the offshoot of the recommendations made by the Banking Commission in its report submitted to the Government of India in 1972. In its report, the commission felt that the existing structure and capabilities of commercial banks and cooperative banks was unable to meet the full credit needs of rural India. It expressed serious doubts about meeting the rural credit needs though maximum branch expansion is done by the commercial banks. It was thought proper and desirable to create an institution which would combine the strong points such as financial strength and managerial competence enjoyed by the commercial banks, rural background and local feel of cooperative banks.

With this background, to meet the above objective, a working group was appointed under the chairmanship of M.Narasimham on $1^{\text {st }}$ July 1975 . Within a short period, the group submitted its report on $30^{\text {th }}$ July 1975 and strongly recommended the new type of institutional setup.

The recommendations of the group accepted by the Government of India and Regional Rural Banks Ordinance of 1975 was promulgated by the President of India on $26^{\text {th }}$ September 1975 . Subsequently this was replaced by the Regional Rural Banks Act on 9 ${ }^{\text {th }}$ February 1976.

A new alternative, low cost, rural minded credit agency was created known as Regional Rural Banks (RRBs) came into existence on $2^{\text {nd }}$ October 1975. The Syndicate Bank sponsored "Prathama Bank" was the first Regional Rural Bank established in Muradabad district of Uttar Pradesh. In addition, other four banks were established one each in Bihar, Haryana, Rajasthan and West Bengal.

\subsection{Aim of the study}

The main objective of the study is to evaluate whether the Regional Rural Banks are able to meet the credit needs of the rural people or not. The specific objectives are as follows.

- To study, review and analyze the functions of RRBs in terms deposit mobilization, advancing, recovery, NPA management etc.

- To check whether RRBs remain as sustainable and viable financial institutions.

- To know the current status of RRBs after many reforms in the banking sector.

- $\quad$ To know how the RRBs have transformed from 1975 till 2019.

\subsection{Methodology}

The present study for its analysis mainly depends on secondary data. The necessary data are collected from various annual reports of NABARD, RBI and various websites. The data collected were analyzed with the help of statistical techniques like percentages, averages, ratio methods. 


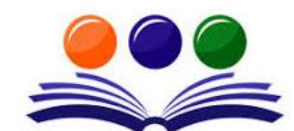

GRAND ACADEMIC PORTAL

RESEARCH JOURNALS
GAP iNTERDISCIPLINARITIES A Global Journal of Interdisciplinary Studies

\author{
( ISSN - 2581-5628) \\ Impact Factor: SJIF - 5.047, IIFS - 4.875
}

\subsection{Objectives of RRBs}

Within 6 years after the nationalization of 14 major commercial banks in the Indian banking history, RRBs were established with the following main objectives.

- $\quad$ To meet banking needs of the small and marginal farmers, rural artisans, landless laborers etc.

- To provide credit at cheaper rates for generating employment and productive purposes particularly in rural areas.

- Removal of poverty in rural areas by increasing income generating capacity of the rural poor.

- To operate with low cost and transact the business in local languages with local feel by recruiting local personnel.

- $\quad$ To stop exploitation of the farmers, ruralites and weaker section by the moneylenders by providing adequate and timely institutional credit at cheaper rates.

- To establish proper banking channels in unbanked and underbanked rural centres and to actively participate in implementation of various schemes/programmes of the government for upliftment of rural weaker sections.

\section{GROWTH OF RRBS}

Regional Rural Banks have been conceived mainly for meeting the requirements of ruralites and to uplift them by providing necessary timely financial assistance. Government of India and other leading agencies took initiation to start RRBs and their bank expansions. The number of RRBs, districts covered and branch expansion from 1975 to 2018 are presented in Table 1.

Table 1

Growth of RRBs (1975-2018)

\begin{tabular}{|c|c|c|c|c|}
\hline Sl. No. & Year & No. of RRBs & $\begin{array}{c}\text { No. of Districts } \\
\text { Covered }\end{array}$ & $\begin{array}{c}\text { No. of } \\
\text { Branches }\end{array}$ \\
\hline 1 & Dec-1975 & 6 & 12 & 17 \\
\hline 2 & Dec-1976 & 40 & 84 & 489 \\
\hline 3 & Dec-1977 & 48 & 99 & 1,187 \\
\hline 4 & Dec-1978 & 51 & 102 & 1,753 \\
\hline 5 & Dec-1979 & 60 & 111 & 2,420 \\
\hline 6 & Dec-1980 & 85 & 144 & 3,279 \\
\hline 7 & Dec-1981 & 107 & 182 & 4,795 \\
\hline 8 & Dec-1982 & 124 & 214 & 6,191 \\
\hline 9 & Dec-1983 & 150 & 265 & 7,795 \\
\hline 10 & Dec-1984 & 173 & 307 & 10,245 \\
\hline 11 & Dec-1985 & 188 & 333 & 12,606 \\
\hline 12 & Dec-1986 & 194 & 351 & 12,838 \\
\hline 13 & Dec-1987 & 196 & 363 & 13,353 \\
\hline 14 & Dec-1988 & 196 & 369 & 13,920 \\
\hline 15 & Mar-1989 & 196 & 369 & 14,079 \\
\hline 16 & Mar-1990 & 196 & 372 & 14,443 \\
\hline 17 & Mar-1991 & 196 & 381 & 14,527 \\
\hline 18 & Mar-1992 & 196 & 392 & 14,539 \\
\hline 19 & Mar-1993 & 196 & 398 & 14,543 \\
\hline 20 & Mar-1994 & 196 & 408 & 14,542 \\
\hline 21 & Mar-1995 & 196 & 425 & 14,509 \\
\hline 22 & Mar-1996 & 196 & 427 & 14,497 \\
\hline 23 & Mar-1997 & 196 & 427 & 14,461 \\
\hline 24 & Mar-1998 & 196 & 451 & 14,459 \\
\hline 25 & Mar-1999 & 196 & 486 & 14,498 \\
\hline 26 & Mar-2000 & 196 & 482 & 14,301 \\
\hline 27 & Mar-2001 & 196 & 501 & 14,313 \\
\hline 28 & Mar-2002 & 196 & 484 & 14,350 \\
\hline 29 & Mar-2003 & 196 & 511 & 14,400 \\
\hline 30 & Mar-2004 & 196 & 518 & 14,446 \\
\hline 31 & Mar-2005 & 196 & 523 & 14,484 \\
\hline 32 & Mar-2006 & 133 & 525 & 14,494 \\
\hline 33 & Mar-2007 & 96 & 534 & 14,520 \\
\hline 34 & Mar-2008 & 91 & 594 & 14,761 \\
\hline 35 & Mar-2009 & 86 & 616 & 15,235 \\
\hline
\end{tabular}




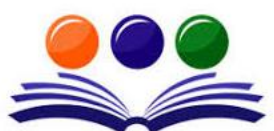

GRAND ACADEMIC PORTAL RESEARCH JOURNALS

\begin{tabular}{|l|l|l|l|r|}
\hline 36 & Mar-2010 & 82 & 618 & 15,480 \\
\hline 37 & Mar-2011 & 82 & 620 & 16,001 \\
\hline 38 & Mar-2012 & 82 & 618 & 16,914 \\
\hline 39 & Mar-2013 & 64 & 635 & 17,861 \\
\hline 40 & Mar-2014 & 57 & 642 & 19,082 \\
\hline 41 & Mar-2015 & 56 & 644 & 20,024 \\
\hline 42 & Mar-2016 & 56 & 644 & 20,920 \\
\hline 43 & Mar-2017 & 56 & 680 & 21,422 \\
\hline 44 & Mar-2018 & 56 & 680 & 21,747 \\
\hline
\end{tabular}

Source: Annual Reports and Statistics on Regional Rural Banks, NABARD, Mumbai It is evident from Table 1 that there has been continuous increase both in the number of RRBs and number of bank branches over the years. Their number has drastically increased from 6 (with 17 branches) in 1975 to 173 (with 10245 branches) in 1984 within a span of 10 years. The number of RRBs increased to 196 by the end of December 1987 and since then no new banks were added. The same status was maintained till 2005. The number of districts covered has also increased from 12 to 363 by the end of December 1987 and further extended to 534 districts by the end of March 2005 with 14484 RRB branch network.

The rural economy witnessed extensive bank branch expansion, taking the number of rural branches to 32719 of which the share of Gramin banks was 44.20 percent with 14462 branches as on $31^{\text {st }}$ March 2000.

The process of amalgamation was started in the banking sector in the year 2005-2006 and as a result, the number of RRBs came down to 133 by the end of $31^{\text {st }}$ March 2006. This process was continued and the number of RRBs drastically reduced to 96 by the end of $31^{\text {st }}$ March 2007 and further reduced to 56 by the end of $31^{\text {st }}$ March 2018. But on the other hand, opening of new branches in unbanked and underbanked rural areas gained momentum. As a result, number of branches of RRBs increased to 21747 by the end of $31^{\text {st }}$ March 2018 . It is evident that RRBs are doing well to reach the rural mass. In the process of financial inclusion, RRBs are playing a vital role by reaching to the doorsteps of rural people.

\section{PERFORMANCE OF RRBS}

The performance of Regional Rural Banks needs to be evaluated from a different angle, such as deposit mobilization, loans and advances, profitability, recovery rate, level of NPA, etc. The RRBs have created a network of 21747 branches across the country mainly concentrating on the rural areas and their outreach is not small.

\subsection{Deposit Mobilization and Loans/advances}

RRBs are able to mobilize the idle savings of rural masses and provide loans and advances to the weaker sections such as small and marginal farmers, rural artisans, landless labourers, etc. to a great extent. Table 2 shows the deposits mobilized, loans and advances given, and C.D ratios over the years.

Table 2

Deposits Mobilized and Loans/Advances

\begin{tabular}{|r|c|r|r|r|}
\hline Sl. No. & Year & \multicolumn{1}{c|}{ Deposits } & \multicolumn{1}{c|}{$\begin{array}{c}\text { Outstanding } \\
\text { Advances }\end{array}$} & C. D. Ratio \\
\hline 1 & Dec-1975 & 0.20 & 0.10 & 50.00 \\
\hline 2 & Dec-1976 & 7.72 & 7.02 & 90.93 \\
\hline 3 & Dec-1977 & 33.04 & 42.35 & 128.18 \\
\hline 4 & Dec-1978 & 74.11 & 122.02 & 164.65 \\
\hline 5 & Dec-1979 & 123.22 & 167.41 & 135.86 \\
\hline 6 & Dec-1980 & 199.83 & 243.38 & 121.79 \\
\hline 7 & Dec-1981 & 336.00 & 406.59 & 121.01 \\
\hline 8 & Dec-1982 & 502.26 & 577.11 & 114.90 \\
\hline 9 & Dec-1983 & 677.85 & 750.84 & 110.77 \\
\hline 10 & Dec-1984 & 959.97 & $1,080.77$ & 112.58 \\
\hline 11 & Dec-1985 & $1,285.82$ & $1,407.67$ & 109.48 \\
\hline 12 & Dec-1986 & $1,714.94$ & $1,784.84$ & 104.08 \\
\hline 13 & Dec-1987 & $2,305.82$ & $2,232.26$ & 96.81 \\
\hline 14 & Dec-1988 & $2,965.88$ & $2,804.29$ & 94.55 \\
\hline 15 & Mar-1989 & $3,118.58$ & $2,918.25$ & 93.58 \\
\hline 16 & Mar-1990 & $4,150.52$ & $3,554.04$ & 85.63 \\
\hline
\end{tabular}




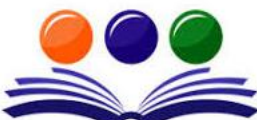 \\ GAP INTERDISCIPLINARITIES A Global Journal of Interdisciplinary Studies}

GRAND ACADEMIC PORTAL RESEARCH JOURNALS

( ISSN - 2581-5628)

Impact Factor: SJIF - 5.047, IIFS - 4.875

\begin{tabular}{|c|c|c|c|c|}
\hline 17 & Mar-1991 & $4,989.24$ & $3,609.27$ & 72.34 \\
\hline 18 & Mar-1992 & $5,867.83$ & $4,090.86$ & 69.72 \\
\hline 19 & Mar-1993 & $6,938.13$ & $4,626.73$ & 66.69 \\
\hline 20 & Mar-1994 & $8,826.51$ & $5,253.02$ & 59.51 \\
\hline 21 & Mar-1995 & $11,150.01$ & $6,290.96$ & 56.42 \\
\hline 22 & Mar-1996 & $14,187.90$ & $7,505.02$ & 52.90 \\
\hline 23 & Mar-1997 & $18,032.01$ & $8,718.08$ & 48.35 \\
\hline 24 & Mar-1998 & $22,189.23$ & $9,860.81$ & 44.44 \\
\hline 25 & Mar-1999 & $27,065.74$ & $11,355.85$ & 41.96 \\
\hline 26 & Mar-2000 & $32,204.34$ & $13,184.25$ & 40.94 \\
\hline 27 & Mar-2001 & $38,271.87$ & $15,816.30$ & 41.33 \\
\hline 28 & Mar-2002 & $44,539.00$ & $18,598.00$ & 41.76 \\
\hline 29 & Mar-2003 & $45,000.00$ & $19,000.00$ & 42.22 \\
\hline 30 & Mar-2004 & $56,350.08$ & $26,113.86$ & 46.34 \\
\hline 31 & Mar-2005 & $62,143.00$ & $32,870.03$ & 52.89 \\
\hline 32 & Mar-2006 & $71,328.83$ & $39,712.57$ & 55.68 \\
\hline 33 & Mar-2007 & $83,143.55$ & $48,492.59$ & 58.32 \\
\hline 34 & Mar-2008 & $99,093.46$ & $58,984.27$ & 59.52 \\
\hline 35 & Mar-2009 & $114,317.45$ & $65,840.78$ & 57.59 \\
\hline 36 & Mar-2010 & $145,034.95$ & $82,819.10$ & 57.10 \\
\hline 37 & Mar-2011 & $166,232.34$ & $98,917.43$ & 59.51 \\
\hline 38 & Mar-2012 & $187,351.37$ & $120,550.66$ & 64.34 \\
\hline 39 & Mar-2013 & $211,488.00$ & $137,078.00$ & 64.82 \\
\hline 40 & Mar-2014 & $239,504.00$ & $159,660.00$ & 66.66 \\
\hline 41 & Mar-2015 & $273,018.00$ & $180,955.00$ & 66.28 \\
\hline 42 & Mar-2016 & $313,499.00$ & $206,538.00$ & 65.88 \\
\hline 43 & Mar-2017 & $371,910.00$ & $226,175.00$ & 60.81 \\
\hline 44 & Mar-2018 & $400,459.00$ & $253,978.00$ & 63.42 \\
\hline
\end{tabular}

Source: Annual Reports and Statistics on Regional Rural Banks, NABARD, Mumbai

It is evident from Table 2 that the RRBs have achieved remarkable growth in deposit mobilization. In the initial few years, deposit mobilization was a bit slow but in subsequent years they achieved a lot. By the end of December 1985, RRBs were able to mobilize Rs 1285.82 crores as against just Rs 20 Lakhs in the year 1975. The deposits mobilized reached Rs 11150.01 crores by the end of March 1995 and the growth rate is nearly 9 fold in a decade. Further by the end of March 2005, it reached Rs 62143 crores, Rs 273018 crores at the end of March 2015 and Rs 400459 crores by the end of 31 ${ }^{\text {st }}$ March 2018. These figures prove that RRBs are able to promote savings habit among the ruralites.

The figures in Table 2 also prove that RRBs are able to provide loans and advances to the needy people in rural areas to a great extent. They have been financing the identified borrowers under different government sponsored programs and schemes. Through self-help groups also they try to reach rural poor especially rural women. The loans and advances given by RRBs has reached Rs 1407.67 crores by the end of December 1985 as against just Rs. 10 lakhs in the year 1975. This amount increased to Rs. 6290.96 crores by the end of March 1995, Rs. 32870.03 crores by the end of March 2005. Within a decade from 2005 to 2015, this has reached Rs. 180955 crores and Rs. 253978 crores by the end of $31^{\text {st }}$ March 2018 . The statistics revealed that out of the total outstanding advances of Rs. 18598 crores, Rs. 11735.97 crores constituting 74.20 percent of the total was from priority sector by the end of March 2002.

\subsection{D. Ratio}

The credit deposit ratio is another criterion for evaluating the performance of RRBs. Table 2 reveals that there is rapid growth of credit- deposit ratio in early stages (up to 1979) and crossing 100 percent mark up to the year 1986.

It has gone up to 164.65 percent in 1978 and thereafter started declining continuously. On 31 st March 2001, the total deposits were Rs. 38271.87 crores and outstanding loans and advances were Rs. 15816.30 crores, as a result the C. D. ratio has drastically come down to 41.33 percent. Again after 2003, it has increased gradually and reached 66.66 percent mark by the end of $31^{\text {st }}$ March 2014 and maintained more or less the same rate. It is interesting to note that though the C.D. ratio is low i.e., between 40 percent and 60 percent, majority of the RRBs earn profit during those years. From the point of view of viability of RRBs is concerned, improvement in C.D. ratio is needed, otherwise the credit management situation will become worser. 


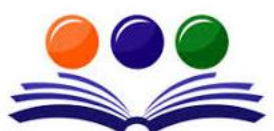

GRAND ACADEMIC PORTAL RESEARCH JOURNALS

\subsection{Non-Performing Assets (NPA)}

The increase in the non-performing assets is an issue of great concern in the Indian banking sector. It has become a serious problem in view of mounting non-performing assets in large volume. Because of high level of NPA, the earning capacity and profitability of many banks has been adversely affected. RRBs are not exception to this and reduction of NPAs is necessary to improve the profitability and for their sustainability. In some years, the net NPA levels vary widely among them, ranging from the dismal level of 56 percent to the incredibly low of 0.43 percent.

Table 3

Recovery rate and NPA of RRBs

\begin{tabular}{|c|r|r|r|}
\hline Sl. No. & Year & Recovery Percentage & NPA Percentage \\
\hline 1 & 2004 & 77.67 & 12.63 \\
\hline 2 & 2005 & 79.85 & 8.50 \\
\hline 3 & 2006 & 79.80 & 7.30 \\
\hline 4 & 2007 & 80.49 & 6.55 \\
\hline 5 & 2008 & 78.00 & 6.05 \\
\hline 6 & 2009 & 77.85 & 5.58 \\
\hline 7 & 2010 & 80.09 & 3.72 \\
\hline 8 & 2011 & 81.18 & 3.75 \\
\hline 9 & 2012 & 81.63 & 4.14 \\
\hline 10 & 2013 & 81.20 & 6.00 \\
\hline 11 & 2014 & 81.90 & 4.40 \\
\hline 12 & 2015 & 79.50 & 6.15 \\
\hline 13 & 2016 & 82.55 & 6.80 \\
\hline 14 & 2017 & 81.00 & 8.07 \\
\hline 15 & 2018 & 78.00 & 9.47 \\
\hline
\end{tabular}

Source: Annual Reports and Statistics on Regional Rural Banks, NABARD, Mumbai

Table 3 reveals that in recent years from 2008-2018 the percentage of NPA varied between 3.72 which is the least and 9.47 which is the highest. The recovery rate is also not satisfactory during the same period. The recovery percentage varies between 77.85 and 82.55 percentage.

\subsection{Profitability}

The C.D. ratio, recovery rate, rate of NPA, employee productivity, operation cost etc., directly effects the profitability of banking institutions. During the initial years, profitability of RRBs was not good. By the end of March 1991, only 44 RRBs out of 196 were making profits and their accumulated losses were Rs. 369.36 crores. After initiating some action plans by different agencies to improve their performance the picture of RRBs has changed. As a result, by the end of $31^{\text {st }}$ March 2001 the number of profit-making RRBs increased to 170 and 30 RRBs attained sustainable viability, building up reserves of Rs. 1265 crores. Out of the total 196 RRBs, 90 RRBs have attained current viability earning profit to the tune of Rs. 172.17 crores, 14 RRBs entered profit arena from loss.

Table 4

Profit/Loss making RRBs

\begin{tabular}{|c|r|r|r|r|r|}
\hline Sl. No. & Year & $\begin{array}{c}\text { RRBs earning } \\
\text { profit }\end{array}$ & $\begin{array}{c}\text { RRBs incurring } \\
\text { losses }\end{array}$ & Amount of profit & Amount of loss \\
\hline 1 & 2004 & 163 & 33 & 952.33 & 183.65 \\
\hline 2 & 2005 & 166 & 30 & 902.60 & 154.49 \\
\hline 3 & 2006 & 111 & 22 & 807.79 & 190.66 \\
\hline 4 & 2007 & 81 & 15 & 926.40 & 301.25 \\
\hline 5 & 2008 & 82 & 8 & $1,383.69$ & 55.58 \\
\hline 6 & 2009 & 81 & 5 & $1,745.84$ & 33.85 \\
\hline 7 & 2010 & 79 & 3 & $2,514.83$ & 5.65 \\
\hline 8 & 2011 & 75 & 7 & $2,420.75$ & 71.32 \\
\hline 9 & 2012 & 79 & 3 & $2,469.18$ & 25.77 \\
\hline 10 & 2013 & 63 & 1 & $2,275.00$ & 2.07 \\
\hline 11 & 2014 & 57 & 0 & $2,833.00$ & 0.00 \\
\hline 12 & 2015 & 51 & 5 & $2,921.00$ & 176.00 \\
\hline 13 & 2016 & 50 & 6 & $2,206.00$ & 188.00 \\
\hline 14 & 2017 & 49 & 7 & $2,604.00$ & 387.00 \\
\hline 15 & 2018 & 45 & 11 & $2,506.00$ & $1,005.00$ \\
\hline
\end{tabular}




\section{$\stackrel{\cdots}{=}$

GRAND ACADEMIC PORTAL

RESEARCH JOURNALS

( ISSN - 2581-5628)

Impact Factor: SJIF - 5.047, IIFS - 4.875

Source: Annual Reports and Statistics on Regional Rural Banks, NABARD, Mumbai

Table 5

RRBs with Accumulated Losses and Reserves

\begin{tabular}{|c|r|r|r|r|}
\hline Sl. No. & Year & $\begin{array}{c}\text { RRBs with accumulated } \\
\text { loss }\end{array}$ & Accumulated losses & Reserves \\
\hline 1 & 2004 & 90 & $2,725.35$ & $3,107.05$ \\
\hline 2 & 2005 & 83 & $2,715.01$ & $3,818.52$ \\
\hline 3 & 2006 & 58 & $2,636.85$ & $4,270.56$ \\
\hline 4 & 2007 & 39 & $2,759.49$ & $4,901.54$ \\
\hline 5 & 2008 & 36 & $2,624.22$ & $5,703.06$ \\
\hline 6 & 2009 & 35 & $2,574.00$ & $6,150.00$ \\
\hline 7 & 2010 & 27 & $1,775.06$ & $8,065.26$ \\
\hline 8 & 2011 & 23 & $1,532.39$ & $9,565.58$ \\
\hline 9 & 2012 & 22 & $1,104.85$ & $11,135.19$ \\
\hline 10 & 2013 & 11 & $1,091.00$ & $13,247.00$ \\
\hline 11 & 2014 & 8 & 903.00 & $15,736.00$ \\
\hline 12 & 2015 & 8 & $1,072.00$ & $18,712.00$ \\
\hline 13 & 2016 & 8 & $1,050.00$ & $20,665.00$ \\
\hline 14 & 2017 & 8 & $1,147.00$ & $23,080.00$ \\
\hline 15 & 2018 & 11 & $1,866.00$ & $25,185.00$ \\
\hline
\end{tabular}

Source: Annual Reports and Statistics on Regional Rural Banks, NABARD, Mumbai

It is evident from Table 4 and Table 5 that from 2004 onwards, the profitability of RRBs has improved. The process of amalgamation was started in the year 2005-2006 and as a result the number of RRBs has come down to 133 out of which 111 RRBs made profits and 22 incurred loss. But 58 RRBs had accumulated losses of Rs. 2636.85 crores in their balance sheets during the same period. After 2008 RRBs have improved their profitmaking position, and gradually the number of loss incurring RRBs came down. At the end of $31^{\text {st }}$ March 2014 all 57 RRBs made profits of 2833 crores and loss incurring number came down to zero. At the same time only 8 RRBs had accumulated loss of Rs. 903 crores. Again 2015 onwards, the loss making RRBs number gradually increased and 11 out of 56 incurred losses of Rs. 2506 crores at the end of $31^{\text {st }}$ March 2018. They were able to strengthen their balance sheets by creating reserves gradually. The total reserves of all the 56 RRBs have reached Rs. 25185 crores at the end of $31^{\text {st }}$ March 2018.

\section{TRANSFORMATION OF RRBS}

Since 1975, Regional Rural Banks have travelled a long way from being regional banks with limited area of operation and finance only target group beneficiaries to viable banks by extending operations to the entire state in some cases. The RRBs have come across mainly 4 stages up to date since inception.

\section{Expansion phase}

During 1975 to 1987 we have seen rapid expansion in RRBs relating to number of banks, branches, volume of business etc. The number of banks increased from 6 to 196, bank branches from 17 to 13353 and number of districts covered from 17 to 363 by the end of Dec 1987. Volume of business also increased many folds during this period.

\section{Declining phase}

The period from 1987 to 1995 is referred as the declining phase. Because of increase in NPA level, cost of operation, declining of C. D. ratio etc., RRBs profitability has declined. Because of increase in number of loss making RRBs and increase in accumulated profits, RRBs business operations turned to unviable stage. The first report of Narasimham Committee (1991) was not favorable to RRBs because of these reasons.

\section{Turn around phase}

The period from 1996 to 2006 is referred as turnaround phase. Second report of Narasimham Committee (1998) recommended so many measures for reforms in banking sector. As a result, measures like recapitalization to RRBs, financing to non-target group, fixing more responsibilities to sponsor banks etc., took place to make these institutions profitable and viable.

4. Consolidation phase

The process of amalgamation was started in the year 2005-06 as the reform measures in banking sector. As a result, number of RRBs has come down to 133 by the end of March 2006, 96 by the end of March 2007 and 56 by the end of March 2015. Government of India initiated amalgamation phase three in the year 


\section{GAP INTERDISCIPLINARITIES A Global Journal of Interdisciplinary Studies ( ISSN - 2581-5628)

2018-19 on the principle of "One State, One RRB" and as a result the number of RRBs further reduced to 45 during 2019-2020.

Various reforms in the banking sector have brought about qualitative as well as quantitative improvements in the performance of regional rural banks. Significant improvement in the performance of RRBs is witnessed in recent years.

The scheme of recapitalization of RRBs was started in 2010-11 and was continued up to 2019-2020 in a phased manner with a financial support of Rs. 2900 crores with 50 percent governments share of Rs. 1450 crores. Up to 2019-2020, out of Rs. 1450 crores, an amount of Rs. 1395.64 crores has been released to RRBs.

\section{CONCLUSION}

The regional Rural banks appeared in the Indian banking map with a number of objectives. In spite of their success and failure, these banks definitely tried to reach the rural mass. These banks which emerged as new species in the arena of Indian banking system have done a good work and have to travel a long way by facing many challenges. In the process of rural development certainly Regional Rural Banks are playing crucial role. Their existence is necessary, and they have to come out with strong, viable institutions in the days to come.

\section{REFERENCES}

[1] Thingalaya N. K., "Gramin Banks in India - A Reassesment”, Justice K. S. Hegde Institute of Management, Nitte, 2001.

[2] Nanjundappa D. M., "Gramin Banks in the Rural Credit System", Problems and Prospects of Rural Banking in India (edited), Mangalore Univerity, 1997.

[3] Revankar Ashok, "Performance Evaluation of Regional Rural Banks - A Case Study of Sahyadri Gramin Bank in Shimoga District", Unpublished Thesis submitted to Kuvempu University, 2007.

[4] Statistics on RRBs, NABARD, Mumbai.

[5] Annual Reports of RBI, Mumbai.

[6] www.nabard.in

[7] www.rbi.in 